$\mathbf{R}_{\text {ESEARCH }} \mathbf{P}_{\text {APER }} \longrightarrow \frac{\text { FOOD SCIENCE }}{\text { RESEARCH JOURNAL }}$

e ISSN-2230-9403 - Visit us : www.researchjournal.co.in Volume 7 | Issue 2 | October, 2016 | 281-285

DOI : $10.15740 / \mathrm{HAS} / \mathrm{FSRJ} / 7.2 / 281-285$

\title{
Acceptability and nutritent content of developed iron rich toffee
}

\author{
T.N. Khan, J.P. NerLekAR AND V.S. ZanVAR
}

The use of green leafy vegetables requires promotion among selected populations to improve micronutrient status. In the present study locally available, uncommonly consumed, low cost, iron rich green leafy vegetables were selected for development of iron rich toffee. Based on results of iron content, rajkeera leaves (Amranthus paniculatus) and Bengal gram leaves (Cicer arietinum L.) were selected. Leaves weredried in mechanical dryer and powder was prepared. Six variations of toffee were prepared using different amounts of green leafy vegetable powder. Acceptability and nutrient content was analyzed. The variation $\mathrm{I}^{\text {st }}$ recorded the highest score for acceptability and iron content.

Key Words : Development of iron rich toffee, Organoleptic evaluation, Nutrient analysis

How to cite this article : Khan, T.N., Nerlekar, J.P. and Zanvar, V.S. (2016). Acceptability and nutritent content of developed iron rich toffee. Food Sci. Res. J., 7(2): 281-285, DOI : 10.15740/HAS/FSRJ/7.2/281-285.

T.N. KHAN, Department of Foods and Nutrition, College of Home Science, Vasantrao Naik Marathwada Krishi Vidyapeeth, PARBHANI (M.S.) INDIA

Email : k_naheed@rediffmail.com

Associate Authors' :

J.P. NERLEKAR, Department of Foods and Nutrition, College of Home Science,

Vasantrao Naik Marathwada Krishi Vidyapeeth, PARBHANI (M.S.) INDIA

Email : jp_nerlekar@rediffmail.com

V.S. ZANVAR, Swami Yoganand Mahavidyalaya, Vasmat, HINGOLI (M.S.) INDIA

Email : vgd_1972@rediffmail.com 